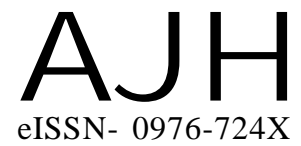

Received : 20.01.2016

Revised : 12.04.2016

Accepted : 24.04.2016

Members of the Research Forum

Associated Authors:

${ }^{1}$ Department of Horticulture, College of Agriculture, Dr. Balasaheb

Sawant Konkan Krishi Vidyapeeth,

Dapoli, RATNAGIRI (M.S.) INDIA

Author for correspondence :

A. KIREETI

Department of Horticulture, College of Agriculture, Dr. Balasaheb

Sawant Konkan Krishi Vidyapeeth,

Dapoli, RATNAGIRI (M.S.) INDIA

Email : itsmekireeti@gmail.com
THE ASIAN JOURNAL OF HORTICULTURE

Volume $11 \mid$ Issue $1 \mid$ June, 2016 | 58-62

Visit us -www.researchjournal.co.in

RESEARCH PAPER

DOI : 10.15740/HAS/TAJH/11.1/58-62

\title{
Studies on effect of types of bag at egg stage on mango fruit (cv. ALPHONSO)
}

\section{A. KIREETI, P.M. HALDANKAR ${ }^{1}$ AND Y.R. PARULEKAR ${ }^{1}$}

ABSTRACT : Bagging of mango fruits prior to harvest is the best alternative to avoid adverse effect of recent changes in climate on fruit by causing physical damage. Bagging mango fruit was undertaken at Department of Horticulture, Dr. Balasaheb Sawant Konkan KrishiVidyapeeth, Dapoli in summer, 2013 from March to June. The results indicated that various chemical parameters were affected significantly due to bagging. Treatment $\mathrm{T}_{1}$ showed best performance for fruit retention $(90.67 \%)$, length $(9.44 \mathrm{~cm})$, weight $(298.67 \mathrm{~g})$ and pulp weight $(223.88 \mathrm{~g})$ of fruit. $\mathrm{T}_{4}$ contributed best performance for days required for harvesting (55 DAB). Bagging had significant effect on mealy bug infestation. Thus, it is concluded that different types of bags influenced growth and development of mango fruit.

KEY WORDS : Alphonso, Bagging, Egg stage, Fruit weight, Mealy bug

HOW TO CITE THIS ARTICLE : Kireeti, A., Haldankar, P.M. and Parulekar, Y.R. (2016). Studies on effect of types of bag at egg stage on mango fruit (cv. ALPHONSO). Asian J. Hort., 11(1) : 58-62, DOI : 10.15740/HAS/TAJH/11.1/58-62. 